\title{
Effect of foliar nutrition of urea and diammonium phosphate on seed yield and economics of sesame (Sesamum indicum L.) under rainfed situation
}

\author{
H.S. MAHAJAN*, Y.G. PATIL, N.A. HIRWE ${ }^{1}$, T.R. PATIL AND M.R. DESHMUKH ${ }^{2}$ \\ Oilseed Research Station (MPKV) JALGAON (M.S.) INDIA \\ (Email : mahajanharichandra@yahoo.com)
}

\begin{abstract}
Field experiments were conducted on deep black soil of Mamurabad farm, Oilseed Research Station, Jalgaon (Maharashtra). Sesame cv. JLT-7 was sown during 2008,2009 and 2010 to find out suitable combination of soil and foliar application of urea and diammonium phosphate for seed yield maximization and remunerative treatments. Result revealed that, soil application of RDF + foliar spray of 2 per cent urea twice at flowering and pod formation stages significantly improved the yield attributes viz., number of capsules plant ${ }^{-1}$ and number of seeds capsule ${ }^{-1}$. These attributes contributed in producing significantly higher seed and oil yields and also proved more remunerative over soil application of RDF alone.
\end{abstract}

Key Words : Sesame, Foliar nutrition, Seed yield, Oil yield, Economics

View Point Article : Mahajan, H.S., Patil, Y.G., Hirwe, N.A., Patil, T.R. and Deshmukh, M.R. (2016). Effect of foliar nutrition of urea and diammonium phosphate on seed yield and economics of sesame (Sesamum indicum L.) under rainfed situation. Internat. J. agric. Sci., 12 (1) : 101-105.

Article History : Received : 01.12.2015; Revised : 13.12.2015; Accepted : 25.12.2015

\footnotetext{
* Author for correspondence

${ }^{1}$ Krishi Vigyan Kendra, Mamurabad farm, JALGAON (M.S.) INDIA

${ }^{2}$ Department of Agronomy, Project Co-ordinating Unit (Sesame and Niger) (JNKVV) JABALPUR (MP) INDIA
} 